J. Clin. Chem. Clin. Biochem.

Vol. 15, 1977, pp. 509-511

\title{
Inhibitory Effect of Histone on the Peroxidase Activity of the $\mathrm{Hp} / \mathrm{Hb}$ Complex
}

\author{
By D. J. Giannitsis
}

Abt. f. Klin. Haemostaseologie und Transfusionsmedizin, Universitätskliniken, 6650 Homburg/Saar, W.-Germany.

(Received July 15, 1976/March 16, 1977)

Summary: The human leukocyte nuclear histones can bind to haptoglobin (Hp), and thus interfere with subsequent binding of $\mathrm{Hb}$. The $\mathrm{Hp} / \mathrm{Hb}$ complex possesses peroxidase activity, but a $\mathrm{Hp} /$ histone complex does not. The inhibitory effect of histone molecules depends directly on the $\mathrm{Hp}$ and $\mathrm{Hb}$, as well as the histone concentrations. The biological significance of the complex $\mathrm{Hp} / \mathrm{Hb}$ as a measure of intravascular hemolysis and the interference of histones in this assay is briefly discussed.

\section{Hemmungseffekt von Histonen auf die Peroxidase-Aktivität des Hp/Hb-Komplexes}

Zusammenfassung: Histone der Kerne menschlicher Leukocyten können Haptoglobin (Hp) binden und die weitere Bindung an $\mathrm{Hb}$ verhindern. Der $\mathrm{Hp} / \mathrm{Hb}$-Komplex weist Peroxidase-Aktivitäten auf, die der Hp-Histon-Komplex nicht besitzt. Der Hemmeffekt der Histonmoleküle ist direkt von den $\mathrm{Hp}$-, Hb- und Histon-Konzentrationen abhängig. Die biologische Bedeutung des $\mathrm{Hp} / \mathrm{Hb}$-Komplexes als $\mathrm{Maß}$ für die intravasale Hämolyse und die Beeinflussung dieses Nachweisversuchs durch Histone wird diskutiert.

\section{Introduction}

It was demonstrated some time ago that haptoglobin $(\mathrm{Hp})$, a group of acidic proteins, has the ability to bind hemoglobin $(\mathrm{Hb})$, and that this $\mathrm{Hp} / \mathrm{Hb}$ complex, like the $\mathrm{Hb}$ or $\mathrm{Hp}$ separately, possesses a high peroxidase activity $(1,2)$. The peroxidase activity of the $\mathrm{Hp} / \mathrm{Hb}$ complex depends on different factors and conditions, which were discussed previously in detail (8).

The binding mechanism of $\mathrm{Hp}$ to $\mathrm{Hb}$ is an electrostatic effect arising from interactions between the positively charged basic $\mathrm{Hb}$ and the negatively charged acidic $\mathrm{Hp}$ molecules (6). The biological significance of this effect is, of course, that the peroxidase activity of $\mathrm{Hp}$, as well as $\mathrm{Hb}$, is smaller than that of the $\mathrm{Hp} / \mathrm{Hb}$ complex, and that the formation of the $\mathrm{Hp} / \mathrm{Hb}$ complex is a measure of intravascular hemolysis.

However, this principle was of value providing it was valid to assume that other biological substances, such as histone, could not hinder the binding of $\mathrm{Hb}$ to $\mathrm{Hp}$. Modifications of the structure of the molecules or changes in the conditions of the binding are accompanied, evidently in vitro, by alterations of the biological functions of the corresponding molecules.

The human leukocyte nuclei histones, a family of five different positively charged basic proteins, are bound in vivo to the chromosomal deoxyribonucleic acid (DNA), following the same molecular mechanism of binding as the $\mathrm{Hp} / \mathrm{Hb}$ complex. The free histones can interact with other molecules ( 3 ) and play an important role in various other biological functions.

Thus free histone can cause alterations in the binding ability of the $\mathrm{Hp}$ to $\mathrm{Hb}$ and, of course, thereby affect the peroxidase activity of the $\mathrm{Hp} / \mathrm{Hb}$ complex.

In the present paper, we report that the human leukocyte nuclear histones can bind to $\mathrm{Hp}$ and thus interfere with subsequent binding of $\mathrm{Hb}$, and that $\mathrm{Hp} /$ histone complexes are devoid of peroxidase activity in contrast to the $\mathrm{Hp} / \mathrm{Hb}$ complex. Moreover, the biological significance of this inhibition effect of histone on the peroxidase activity of the $\mathrm{Hp} / \mathrm{Hb}$ complex and the use of its assay as a measure of intravascular hemolysis, is briefly discussed.

\section{Materials and Methods}

Preparation of histone

Leukocytes from human blood, and leukocyte nuclei, were isolated by the method previously described (3). The nuclei pellets of human leukocytes were treated with $0.25 \mathrm{~mol} / \mathrm{l}$ $\mathrm{NaCl}$. The clear supernatant was separated from the nuclei after centrifugation at $2600 \mathrm{~g}$ for $30 \mathrm{~min}$ at $+4{ }^{\circ} \mathrm{C}$. The histones were then precipitated by slow addition of six volumes of cold acetone. The precipitate was prepared by centrifugation, washing 3 times in acetone and ether, and drying under vacuum. 
The histones were tested by amino acid analysis as well as by electrophoresis. The protein concentration was checked photometrically.

\section{Preparation of hemoglobin}

Human erythrocytes washed five times with saline, were diluted with four parts of water. After careful acidification with $0.1 \mathrm{~mol} / 1 \mathrm{HCl}$ to $\mathrm{pH} 5,8$, the erythrocyte membranes were removed by centrifugation. The solution was then neutralized to $\mathrm{pH} 7.2$ with $0.1 \mathrm{~mol} / 1 \mathrm{NaOH}$, centrifuged once again to remove any precipitate, diluted so as to contain exactly $30 \mathrm{~g} / \mathrm{l}$ of hemoglobin, and stored at $-20^{\circ} \mathrm{C}$ (stock solution).

Before use an amount of the stock solution was diluted with saline $(600 \mathrm{mg} / \mathrm{l}$ hemoglobin).

\section{Materials}

Commercial calf-thymus histones, used as control, were obtained from Sigma Chemical Co. (St. Louis, Mo.). Hydrogen peroxide $0.015 \mathrm{~mol} / 1$ diluted from a stock solution of $300 \mathrm{~g} / \mathrm{kg}$ (Perhydrol, Merck, Germany); fresh dilutions were prepared each day and standardized by permanganate titration. All other reagents used were of analytical grade. $o$-Dianisidine reagent was prepared by dissolving $1 \mathrm{~g} o$-dianisidine (Merck, Germany), $0.5 \mathrm{~g}$ EDTA and $15.6 \mathrm{~g}(0.2 \mathrm{~mol})$ of $\mathrm{NaH}_{2} \mathrm{PO}_{4} \cdot 2 \mathrm{H}_{2} \mathrm{O}$ in one liter of distilled water and adjusting the solution carefully to $\mathrm{pH} 4,10$ with $\mathrm{H}_{3} \mathrm{PO}_{4}$.

\section{Assay of peroxidase activity}

The assay of the peroxidase activity was performed according to l. c. (5) as follows: $0.2 \mathrm{ml}$ of serum of healthy donors was mixed with $1.0 \mathrm{ml}$ of the diluted Hb-solution $(600 \mathrm{mg} / \mathrm{l} \mathrm{Hb})$ in a small tube, incubated $10 \mathrm{~min}$ at $37^{\circ} \mathrm{C}$; then $0.02 \mathrm{ml}$ of the mixture was transfered to a test tube containing $5 \mathrm{ml}$ of $o$-dianisidine reagent.

The assay of histone on the $\mathrm{Hp} / \mathrm{Hb}$ system was performed as follows: To $0.2 \mathrm{ml}$ of serum was added $1.0 \mathrm{ml}$ of a histone solution $(0.6 \mathrm{~g} / \mathrm{l})$; after incubation for $10 \mathrm{~min}$ at $37^{\circ} \mathrm{C} 1.0 \mathrm{ml}$ of the diluted $\mathrm{Hb}$-solution $(600 \mathrm{mg} / \mathrm{l})$ was added. The peroxidase activity was then determined according to the 0 -dianisidine procedure, as in the measurement of the catalase activity of $\mathrm{Hp} /$ $\mathrm{Hb}$.

To study the influence of histone on the peroxidase activity of the $\mathrm{Hp} / \mathrm{Hb}$ complex, the $\mathrm{Hp} / \mathrm{Hb}$ mixture was incubated for $10 \mathrm{~min}$, followed by the addition of a histone solution.

Each series of analyses should include a reagent blank (water instead of the serum) and a standard of haptoglobin (a serum sample known to contain an excess haptoglobin). The mixture was incubated for $15 \mathrm{~min}$, followed by the addition of $1.0 \mathrm{ml}$ of $0.015 \mathrm{~mol} / 1 \mathrm{H}_{2} \mathrm{O}_{2}$ to every tube. Absorbance was measured against the blank at $395 \mathrm{~nm}$ (Zeiss, Spektralphotometer, model PM 2 DL).

The peroxidase activity was finally calculated with the aid of a standard curve.

\section{Results and Discussion}

The $\mathrm{Hp} / \mathrm{Hb}$ complex possesses classical $(1,2)$ peroxidase activity, and the level of activity depends on the $\mathrm{Hp}$ and $\mathrm{Hb}$ concentrations. This is depicted in the graph shown in figure 1. From this it can be seen that the peroxidase activity is directly proportional to the $\mathrm{Hb}$ concentrations for the range of $300-800 \mathrm{mg} / \mathrm{l} \mathrm{Hb}$, for a standard concentration of $\mathrm{Hp}(0.2 \mathrm{ml}$ pool serum of 12 healthy individuals).

Human leukocyte nuclear histones show an inhibitory effect on the peroxidase activity of $\mathrm{Hp} / \mathrm{Hb}$ complexes. This inhibitory effect can be demonstrated using the decrease in peroxidase activity of $\mathrm{Hb} / \mathrm{Hp}$ complexes in the presence of histones. Figure 2 demonstrates the in-

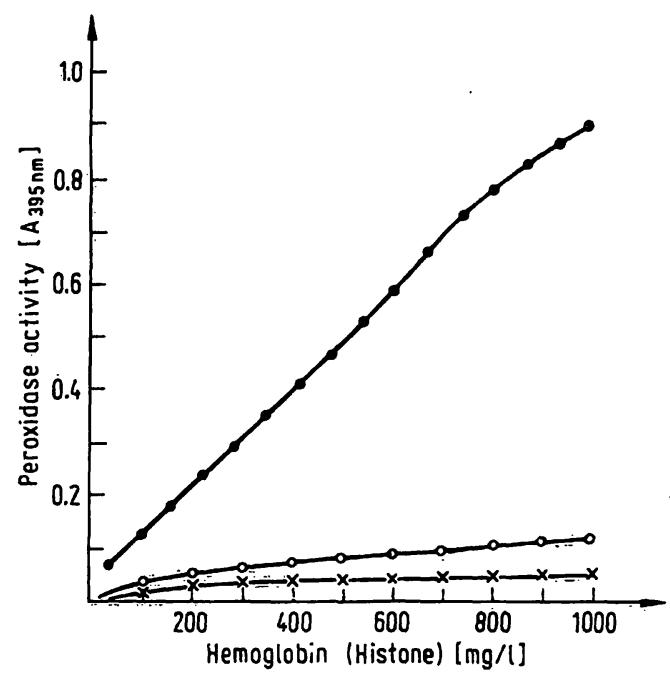

Fig. 1. The peroxidase activity of the complex $\mathrm{Hp} / \mathrm{Hb}(\bullet-\bullet-\bullet)$, the $\mathrm{Hb}(0-0-0)$ and the histone $(x-x-x)$ (for detail see text).

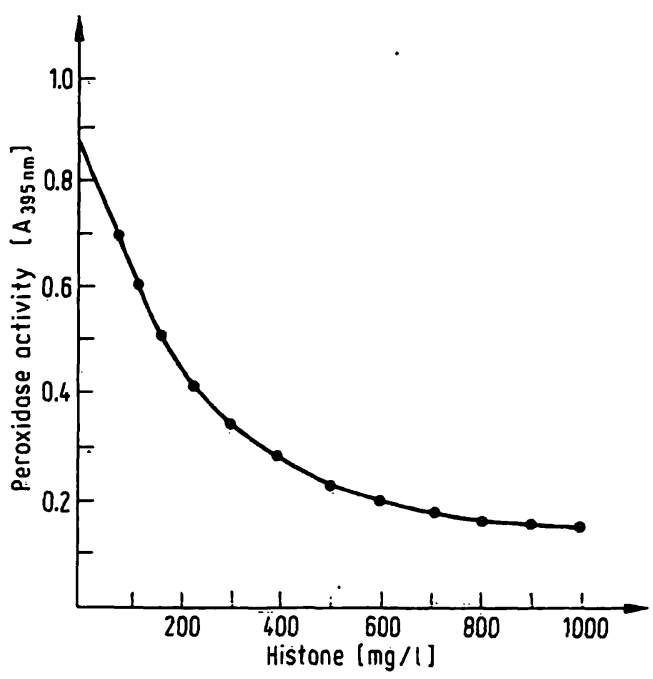

Fig. 2. The inhibition effect of histone on the binding ability of $\mathrm{Hb}$ to $\mathrm{Hp}$ (in form as reduced peroxidase activity from $\mathrm{Hb} / \mathrm{Hp}$ complex). Preincubation: Serum + histone, incubation $10 \mathrm{~min}$ at $37^{\circ} \mathrm{C}$ and then addition of $1,0 \mathrm{ml} \mathrm{Hb}$ (diluted $\mathrm{Hb}$-solution). Addition of histone after incubation of Hb-serum hasn't any inhibition effect on the binding of $\mathrm{Hp} / \mathrm{Hb}$ complex (for detail see text).

hibitory effect of histones on the peroxidase activity of the $\mathrm{Hp} / \mathrm{Hb}$ complex.

Moreover, it is demonstrated, that the addition of $\mathrm{Hb}$ to a preformed Hp-histone complex remains ineffective, namely the interaction of $\mathrm{Hp}$-histone cannot be reversed after the addition of $\mathrm{Hb}$.

The results of these studies indicate, that the human leukocyte nuclear histones inhibit the peroxidase activity of $\mathrm{Hp} / \mathrm{Hb}$ complexes, and that this phenomenon cannot be reversed. In our laboratory, we found, using immunological methods, an augmentation of the histone concentration in blood plasma during blood storage (9). The interactions between histones, $\mathrm{Hb}$ and $\mathrm{Hp}$ molecules could be electrostatic, between positively charged and negatively charged molecules. Similar mole- 
cular interactions are well known (for review see 1. c. (4), (6)). Recently, it was demonstrated (3) that, after a recombination procedure between histones and DNA molecules, according to the concept and method of Johns \& Forester (7), changes occur in the binding ability of the molecules, probably due to denaturation of the molecules. This alteration is accompanied, of course, by alterations in the biological functions of the corresponding molecules.

However, an interpretation of the selective binding between histones, $\mathrm{Hb}$ and $\mathrm{Hp}$, is possible on the basis of molecular interactions between electrostatically different molecules (6).

In conclusion, it appears that human leukocyte nuclear histones can bind to Hp and that the histone-Hp-complexes are devoid of peroxidase activity, in contrast to $\mathrm{Hb} / \mathrm{Hp}$ complexes. The biological significance of this phenomenon is, that peroxidase activity is not a true measure of intravascular hemolysis, because the leukocyte histones, during cell destruction, can interfere on the formation of $\mathrm{Hp} / \mathrm{Hb}$ complexes and hinder the binding of $\mathrm{Hb}$ to $\mathrm{Hp}$. Thereafter, the free $\mathrm{Hb}$ molecules can have a false peroxidase activity. Moreover, it is demonstrated, that the decrease in peroxidase activity of $\mathrm{Hp} /$
$\mathrm{Hb}$ complexes can be used as a measure for the histonebinding or an assay for the degree of histone-inhibition on the $\mathrm{Hp} / \mathrm{Hb}$ complex formation.

\section{Conclusion}

Structural modifications of cell membranes, as an agglutination of human erythrocytes, are accompanied by intracellular metabolic alterations. The human leukocyte nuclei histones and their subfractions can cause agglutination and/or a hemolysis of human erythrocytes. This phenomenon is specific for the cell membrane receptors of the "ABO blood" group system of the human erythrocytes. The degree of the agglutination and hemolysis depends on the specificity of the erythrocyte membrane receptors, as well as on the structure of histone molecules (different histone fractions) and the protein concentration.

The significance of our results is that the presence of free histones in blood plasma can cause immunological reactions by erythrocytes and probably lymphocytes; with respect to the blood storage and preservation this is of great theoretical and practical interest.

\section{References}

1. Jayle, M. F. (1940), C. R. Acad. Sci., 211, 574.

2. Jayle, M. F. (1962), Les Haptoglobines: Etude biochimique, génétique et physiopathologique. Masson \& Cie. p. 8.

3. Giannitsis, D. J. \& Pappas, A. (1975), Abstracts of International Society of Hematology, 3. p. 2:10, London.

4. Boseley, G. P., Bradbury, F. M., Butler-Browne, G. S., Carpenter, B. G. \& Stephens, R. M. (1976), Eur. J. Biochem. $62,21-31$.

5. Tarukoski, P. H. (1966), Scand. J. Clin. Lab. Invest., 18. 80-86.

6. Lewis, P. N. \& Bradbury, E. M. (1974), Biochim. Biophys. Acta, 336, 153-164.

7. Johns, E. W. \& Forester, S. (1970), Biochim. Biophys. Acta 209, 54-00.

8. Mattenheimer, H. \& Adams, E. C. (1968), this J. 6, 69-78.

9. Giannitsis, D. J. (manuscript in preparation).

Dr. D. J. Giannitsis Universitätskliniken $6650 \mathrm{Homburg} / \mathrm{Saar}$ 
